\title{
Nutritional ecology of blowflies (Diptera, Calliphoridae): estimates of critical larval weight for pupation on two different diets
}

\author{
Cássio da Silva Ribeiro ${ }^{1} \&$ Cláudio José Von Zuben ${ }^{1}$
}

'Departamento de Zoologia/ Instituto de Biociências - Universidade Estadual Paulista - Campus de Rio Claro. Avenida 24A, 1515, Caixa Postal 199, Bairro Bela Vista, 13506-900 Rio Claro-SP, Brasil. cassiosr@gmail.com, vonzuben@rc.unesp.br

\begin{abstract}
Nutritional ecology of blowflies (Diptera, Calliphoridae): estimates of critical larval weight for pupation on two different diets. Under natural environmental conditions, blowflies utilize discrete and ephemeral feeding resources such as decaying carcasses. Competition for food on such feeding substrates is usually very severe, and only the individuals that are capable of attaining the critical larval weight for pupation will be able to survive. This critical weight is hitherto unknown for several blowfly species; therefore, the current work is aimed at obtaining such a critical value for four blowfly species of the genera Chrysomya and Lucilia, deploying two types of feeding substrate, namely, artificial diet and macerated bovine meat. On the whole, the critical weights ranged from 30 to $35 \mathrm{mg}$. The lowest larval weight which permitted pupation was $30.0 \mathrm{mg}$ for Chrysomya megacephala reared on macerated bovine meat. This species was also the best adapted to pupation at low larval weights in relation to the maximum larval weight for males. Regarding the pupation of females, the best-adapted individual was a C. albiceps specimen exhibiting a critical weight that was equal to $39.20 \%$ of the maximum value obtained. Concerning all the species and diet types, the female individuals exhibited the lowest critical weights that produced viable pupae, probably representing an evolutionary strategy that favoured the survival of females, responsible for the egg formation, contributing to the establishment of future generations. Regarding the loss (in percentage) of adult biomass in relation to the third instar larvae, the females of C. megacephala lost less weight than males in both feeding substrates. On the other hand, such a loss of weight occurred in males of C. albiceps and $L$. cuprina.
\end{abstract}

KEYWORDS. Calliphorids; competition; food; larvae; minimum weight.

\begin{abstract}
RESUMO. Ecologia nutricional de moscas-varejeiras (Diptera, Calliphoridae): estimativas de peso larval crítico para pupação em duas diferentes dietas. Em ambiente natural, as moscas-varejeiras utilizam como alimento, substratos discretos e efêmeros, como por exemplo, carcaças em decomposição. Normalmente, o nível de competição por alimento nesses substratos é bastante severo, e somente vão sobreviver os indivíduos que atingiram o peso larval crítico para pupação. Como esse valor não é conhecido para várias espécies de moscas-varejeiras, o objetivo do presente trabalho foi de obter esse peso crítico para quatro espécies de moscas-varejeiras dos gêneros Chrysomya e Lucilia, em dois tipos de substrato alimentar: dieta artificial e carne bovina moída. Os pesos críticos geralmente se situaram na faixa de 30 a $35 \mathrm{mg}$. O menor peso larval que permitiu a pupação foi de $30,0 \mathrm{mg}$ em C. megacephala criada em carne bovina moída. Esta espécie também foi a mais adaptada a empupar com pesos larvais baixos em relação ao peso larval máximo para machos. Já a fêmea melhor adaptada a empupar foi uma C. albiceps com peso crítico representando $39,20 \%$ do máximo obtido. Os menores pesos críticos que deram origem a pupas foram observados em fêmeas, para todas as espécies e dietas, representando provavelmente uma estratégia evolutiva que procura privilegiar a sobrevivência das fêmeas, responsáveis pela formação dos ovos, contribuindo para a formação das futuras gerações. Já com relação à perda em porcentagem, de biomassa do adulto em relação às respectivas larvas de terceiro instar, em C. megacephala as fêmeas perderam menos peso que os machos em ambas as dietas, sendo que para C. albiceps e L. cuprina, isto ocorre com os machos.
\end{abstract}

PALAVRAS-CHAVE. Alimento; califorídeos; competição; larvas; peso mínimo.

Food sources like feces, carcasses, fruits, fungi and decaying plants, are separate units and provide food for many animal species. These substrates are small and ephemeral and provide a limited amount of food (Hanski 1987).

The organisms that use these resources often face severe levels of competition and, for those that present competition of the exploitative type, each one search to eat food as quickly as possible before the complete exhaustion of resources (De Jong 1976, Lomnicki 1988). The results of this competition reflected in population parameters such as survival, fecundity and size of adults (Reis et al. 1994).

Examples of animals showing this type of competition are the larvae of blowfly species of the genera Chrysomya (Robineau-Desvoidy) and Lucilia (Robineau-Desvoidy), which have considerable importance to public health and may be mechanical vectors of pathogens for humans, cause facultative myiasis in animals and humans, as well as being used in studies of legal medicine as forensic indicators (Zumpt 1965; Furlanetto et al. 1984; Greenberg 1991; Guimarães \& Papavero 1999). Moreover, the species Chrysomya megacephala (F.) is responsible for economic losses in Southeast Asian countries, where the fish exposed to the sun is constantly attacked by males and females of this species in search of food and oviposition sites, causing severe losses (Esser 1990, 1991).

The survival of competitors for ephemeral resources will also depend on the time of development (Slansky \& Rodriguez 1987). Thus, the larvae that reach a minimum larval weight or the critical weight in a shorter time than others, have greater chances of survival. This critical weight is defined as the 
minimum larval mass in which additional growth would not be necessary for the normal course of pupation (Ochieng' Odero-1992; Davidowitz et. al. 2003), this being different for each species (Levot et al. 1979).

Artificial diets that have a more pleasant odor and a good cost benefit relationship have been used for the maintenance of species of flies in the laboratory. These diets present number and size of individuals equivalent to those created with meat (Leal et al. 1982; Constable \& Griffith 1986; Taylor \& Mangan 1987; Schmidt \& Harris 1989; Chaudhury \& Alvarez 1999; Tachibana \& Numata 2001).

Data on minimum larval weight for pupation obtained experimentally with the use of diets based on meat and artificial diets are rare in the literature. Levot et al. (1979) studied the larval growth of some species of Calliphoridae and Sarcophagidae in beef liver, and estimated their critical larval weights for pupation. Von Zuben (1998) studied the minimum larval weight for pupation in Chrysomya megacephala (F.) using an artificial diet.

Therefore, more detailed studies of larval critical weight for pupation for different blowfly species, growing in different conditions, are necessary. The objective of this study is to observe what is the critical larval weight for pupation in four blowfly species of the genera Chrysomya and Lucilia, developing on two different feeding substrates, under laboratory conditions. The weight loss of the emerging adults in relation to the respective third instar larvae was also calculated.

\section{MATERIAL AND METHODS}

Blowflies were collected in the Biosciences Institute of UNESP in Rio Claro, SP, Brazil, with the aid of a hand net and baits made with beef rotting. Once identified, especimens of Chrysomya albiceps (Wied), C. megacephala, L. eximia (Wied) and L. cuprina (Wied) were separated, each species in a cage at $25 \pm 1{ }^{\circ} \mathrm{C}$ and a 12 hours photoperiod. Subsequently, the $\mathrm{F}_{1}$ generation of each species was obtained, whose larvae were kept in bottles with ground beef in climate chambers at $25 \pm 1^{\circ} \mathrm{C}$ and a 12 hours photoperiod.

From the oviposition of the $\mathrm{F}_{1}$ generation 100 larvae of each species were collected, forming the $\mathrm{F}_{2}$ generation. These larvae were separated and placed in vials containing macerated bovine meat (50 larvae) and artificial diet according to Leal et al. (1982) (other 50 larvae). Third instar larvae were removed from the flasks, washed, dried and weighed on an analytical balance. These larvae were isolated in small plastic bottles numbered, with a substrate of wood shavings, covered with organza and kept under the same conditions as before. From the viable pupae, the sex of the adults that emerged was determined, to obtain the minimum larval weight for pupation.

The maximum larval weights were determined by separating 50 larvae of the F2 generation and placing them in separate bottles for each species under the same conditions of the substrates used to obtain the minimum larval weight. The third instar larvae, when they began to leave the food substrate for pupation, were removed, washed, dried, weighed and individualized, as before. The emerging adults were sexed and the maximum larval weight for each species and sex was considered as the largest larval weight giving rise to a viable adult.

The ability to pupation (percentage in relation to the maximum larval weight for each species) was calculated using the formula $\%=\frac{A}{B} \times 100$, where $A$ corresponds to the minimum larval weight and $B$, the maximum larval weight for each species.

After the emerging adults have completed their cycle, we waited until the complete relaxation of its wings and then they were weighed and sexed. The calculation of the loss of biomass was done using the following formula:

The average weight loss of the larva until the adult stage $=\left\{\frac{P l-P a}{P l}\right\} \times 100$, where $P l$ is the larval weight, and $P a$ is the adult weight.

\section{RESULTS}

Table I shows all the values of critical larval weight for pupation found for the four species studied. The lowest larval weight obtained was $30 \mathrm{mg}$, resulting in a female of $C$. megacephala created in ground beef. For the same species, the lowest larval weight necessary for pupation on artificial diet was $32.8 \mathrm{mg}$, also resulting in a female.

For $C$. albiceps, the lowest larval weight necessary for pupation was $31.4 \mathrm{mg}$ in female bred in macerated bovine meat.

The species of the genus Lucilia presented minimum larval weights of $32.6 \mathrm{mg}$ and $33.2 \mathrm{mg}$, respectively, for $L$. eximia and L. cuprina treated in macerated bovine meat and resulted in females.

After the larvae stop the feeding, due to food shortages or satiety, those who achieve the minimum larval weight for pupation tried to pupate. The results shown in Table II demonstrate the loss of biomass, in percentage, of the adults in relation to the respective third instar larvae, and indicated that the greatest losses occurred in females and males of $L$. cuprina, with 22.86 and $19.61 \%$ loss of biomass in artificial diet. In ground beef, the largest losses occurred in females of L. cuprina and males of C. megacephala, with 21.27 and $17.13 \%$ loss, respectively.

With respect to maximum larval weight, the specimen with

Table I. Critical larval weights (mg) necessary to pupation, separated by sexes and diets for the different species studied.

\begin{tabular}{llcc}
\hline & & \multicolumn{2}{c}{ Minimum weight (mg) } \\
\cline { 3 - 4 } Species & Diets & females & males \\
\hline Chrysomya albiceps & artificial & 31.5 & 34.8 \\
Chrysomya albiceps & beef & 31.4 & 32.6 \\
Chrysomya megacephala & artificial & 32.8 & 35.1 \\
Chrysomya megacephala & beef & 30 & 33.4 \\
Lucilia eximia & artificial & 34.1 & 34.4 \\
Lucilia eximia & beef & 32.6 & 34.1 \\
Lucilia cuprina & artificial & 33.4 & 37.3 \\
Lucilia cuprina & beef & 33.2 & 34.3 \\
& & &
\end{tabular}


Table II. Mean loss weight (in percentage) between adults and third instar larvae for the different species, separated by diets and sexes.

\begin{tabular}{lccccc}
\hline \multirow{2}{*}{ Species } & \multicolumn{2}{c}{ Artificial diet } & & \multicolumn{2}{c}{ Ground beef } \\
\cline { 2 - 3 } \cline { 6 - 7 } & Females & Males & & Females & Males \\
\cline { 2 - 3 } \cline { 5 - 6 } & adult- & adult- & & adult- & adult- \\
& larva & larva & & larva & larva \\
\hline Chrysomya albiceps & 18.31 & 15.37 & & 15.85 & 14.05 \\
Chrysomya megacephala & 18.03 & 18.43 & & 15.57 & 17.13 \\
Lucilia eximia & 17.98 & 14.93 & & 15.54 & 16.46 \\
Lucilia cuprina & 22.86 & 19.61 & & 21.27 & 15.76 \\
\hline
\end{tabular}

the highest value was a male of $C$. megacephala, created in an artificial diet with a weight of $100.4 \mathrm{mg}$. The largest female was also obtained in C. megacephala, with $81.4 \mathrm{mg}$, obtained in diet of ground beef. The results are shown in Table III.

Table IV shows that the species best suited to pupate with low larval weight in relation to the maximum larval weight was $C$. megacephala with $34.96 \%$ of the maximum larval weight for males, in artificial diet. The better adapted female was of $C$. albiceps, with $39.20 \%$ of the highest weight obtained, in ground beef.

\section{DISCUSSION}

In this study, some aspects of nutritional ecology of four blowfly species were studied, with emphasis on larval competition for food and minimum larval weight for pupation. It has been shown that for many insects, it is necessary to reach a critical larval weight for the occurrence of pupation (minimum weight for pupation) in its last instar (Ochieng' Odero-1992; Davidowitz et al. 2003).

The pupation and the subsequent adult emergence are possible only if the third instar larvae reach the minimum weight before the complete lack of its food source (Von Zuben 1998). In studies of weevils, it was observed that hunger can cause the complete desiccation of specimens in the cocoons, and is considered the major cause of natural deaths (Reardon \& Spurgeon 2002).

Competition for food in blowflies is regarded as exploitative, where each larva attempts, independently, eat as much as possible until the complete food exhaustion (Levot et al. 1979, Lomnicki 1988, Godoy et al. 1996).

The result of competition for food is related to the degree of food assimilation by the competitors. In studies

Table III. Maximum larval weights (mg), separated by sexex and diets in the different species.

\begin{tabular}{lccc}
\hline & & \multicolumn{2}{c}{ Maximum weight $(\mathrm{mg})$} \\
\cline { 3 - 4 } Species & Diets & females & males \\
\hline Chrysomya albiceps & artificial & 77.3 & 81.9 \\
Chrysomya albiceps & beef & 80.1 & 75.3 \\
Chrysomya megacephala & artificial & 77.3 & 100.4 \\
Chrysomya megacephala & beef & 81.4 & 73.9 \\
Lucilia eximia & artificial & 77 & 79.5 \\
Lucilia eximia & beef & 80.3 & 81.6 \\
Lucilia cuprina & artificial & 75.1 & 72.9 \\
Lucilia cuprina & beef & 76.6 & 74.2 \\
\hline
\end{tabular}

Table IV. Percentage (\%) of the maximum larval weight.

\begin{tabular}{lccc}
\hline & & \multicolumn{2}{c}{ Percentage (\%) } \\
\cline { 3 - 4 } Species & Diets & females & males \\
\hline Chrysomya albiceps & artificial & 40.75 & 42.49 \\
Chrysomya albiceps & beef & 39.2 & 43.29 \\
Chrysomya megacephala & artificial & 42.43 & 34.96 \\
Chrysomya megacephala & beef & 41.84 & 45.19 \\
Lucilia eximia & artificial & 44.29 & 43.27 \\
Lucilia eximia & beef & 40.6 & 41.79 \\
Lucilia cuprina & artificial & 44.47 & 51.17 \\
Lucilia cuprina & beef & 43.34 & 46.23 \\
\hline
\end{tabular}

with insects, Slansky \& Rodriguez (1987) determined that the performance of the immature individual is genetically determined. Thus, insects that can assimilate resources more efficiently are those with a higher fitness, and not necessarily those who ate a greater quantity of food (Putman 1977; Slansky \& Rodriguez 1987; Von Zuben 1993).

One of the adaptive advantages for this type of competition is that the species which have a low critical weight for pupation can get down in the process of pupation in a shorter time than others, and thus are more likely to give rise to adults (Lomnicki 1988, Von Zuben 1998).

In this study, the minimum larval weights necessary to pupation were ranging between 30 to $35 \mathrm{mg}$, with the exception of two cases with weights a little higher than $35 \mathrm{mg}$, and the lighter weight that allowed larval pupation was 30,0 $\mathrm{mg}$ in C. megacephala created in ground beef. Analyzing the two diets used, it was not possible to determine which of the diets that provided a better condition for the development of the larvae. The best results on the ability of pupation with larval weight below the optimum were obtained in the two diets, but for different sexes.

The species most adapted to pupate with lighter larval weight in relation to the maximum was $C$. megacephala with $34.96 \%$ of the maximum larval weight, for males in artificial diet. This result confirms that obtained by Levot et al. (1979), who observed that $C$. megacephala is the species best adapted to pupate with low larval weights. The female better adapted to pupate was a $C$. albiceps with $39.20 \%$ of the maximum weight, in macerated bovine meat.

Another interesting aspect of this study was the fact that the lowest minimum weights that gave rise to pupae were observed in females for all species and diets, representing probably an evolutionary strategy that seeks to favor the survival of females responsible for the formation of eggs, contributing to the formation of future generations.

In relation to biomass loss in adults, in percentage, related to their respective third instar larvae in C. megacephala, females lost less weight than males in both diets, and for $C$. albiceps and L.cuprina, this occurs with males.

The results of the present study suggest that the species that achieves pupation with the lowest weight in relation to its maximum larval weight, and that less lose weight at adult emergence in relation to its respective third instar, should take advantage over competitors in situations of limited food resources. Thus, further studies are needed to further 
elucidate the differences in competitive ability among species of blowflies using the food substrate.

Acknowledgments. CJVZ has a grant from CNPq.

\section{REFERENCES}

Chaudhury, M. F. \& L. A. Alvarez. 1999. A new starch-grafted gelling agent for screwworm (Diptera: Calliphoridae) larval diet. Journal of Economic Entomology 92: 1138-1141.

Constable, S. A. \& I. P. Griffith. 1986. Diets for rearing axenic Lucilia cuprina. Journal of the Australian Entomological Society 25: 30.

De Jong, G. 1976. A model of competition for food. 1976. I. Frequencydependent viabilities. American Naturalist 110: 1013-1027.

Davidowitz, G.; L. J. D'amico \& H. F. Nijhout. 2003. Critical weight in the development of insect body size. Evolution and Development 5: 188-197.

Esser, J. R. 1990. Factors influencing oviposition, larval growth and mortality in C. megacephala (Diptera: Calliphoridae), a pest of salted dried fish in south-east Asia. Bulletin of Entomological Research 80: 369-376.

Esser, J. R. 1991. Biology of C. megacephala (Diptera: Calliphoridae) and reduction of losses caused to salted-dried fish industry in south-east Asia. Bulletin of Entomological Research 81: 33-41.

Furlanetto, S. M. P.; M. L. C. Campos \& C. M. Harsi. 1984. Microrganismos enteropatogênicos em moscas africanas pertencentes ao gênero Chrysomya (Diptera: Calliphoridae) no Brasil. Revista de Microbiologia 15: $170-174$.

Godoy, W. A. C.; S. F. Reis \& C. J. Von Zuben. 1996. Larval dispersal in Chrysomya megacephala, Chrysomya putoria and Cochliomyia macellaria (Diptera: Calliphoridae). Ecological implications of aggregation behavior. Journal of Applied Entomology 120: 423-426.

Greenberg, B. 1991. Flies as forensic indicators. Journal of Medical Entomology 28: 565-577.

Guimarães, J. H. \& N. Papavero. 1999. Myiasis in man and animals in the Neotropical Region. São Paulo, Editora Plêiade, 308 p.

Hanski, I. 1987. Nutritional ecology of dung- and carrion-feeding insects, p. 837-884. In: F. Slansky \& F. G. Rodriguez (ed.) Nutritional ecology of insects, mites, spiders, and related invertebrates. New York, John Wiley \& Sons, 1032 p.

Leal, T. T. S.; A. P. Prado \& A. J. Antunes. 1982. Rearing the larvae of the blowfly Chrysomya chloropyga (Diptera, Calliphoridae) on oligidic diets. Revista Brasileira de Zoologia 1: 41-44.

Levot, G. W.; K. R. Brown \& E. Shipp. 1979. Larval growth of some calliphorid and sarcophagid Diptera. Bulletin of Entomological Research 69: 469-475.

Lomnicki, A. 1988. Population ecology of individuals. Princeton, Princeton Press, $223 \mathrm{p}$.

Ochieng'- Odero, J. P. R. 1992. The effect of three constant temperatures on larval critical weight, latent feeding period, larval maximal weight and fecundity of Cnephasia jactatana (Walker) (Lepidoptera: Tortricidae). Journal of Insect Physiology 38: 127-130.

Putman, R. J. 1977. Dynamics of the blowfly, Calliphora erythrocephala, within carrion. Journal of Animal Ecology 46: 853-866.

Reardon, B. J. \& D. W. Spurgeon. 2002. Critical weights of boll weevil (Coleoptera: Curculionidae) larvae in relation to square desiccation and natural mortality. Enviromental. Entomology 31: 972-976.

Reis, S. F.; G. Stangenhaus; W. A. C. Godoy; C. J. Von Zuben \& O. B. Ribeiro. 1994. Variação em caracteres bionômicos em função de densidade larval em Chrysomya megacephala e Chrysomya putoria (Diptera: Calliphoridae). Revista Brasileira de Entomologia 38: 33-34.

Schmidt, C. D. \& R. L. Harris. 1989. Comparison of production of larvae of Chrysomya rufifacies in meat and in a gelled medium. The Southwestern Entomologist 14: 67-70.

Slansky, F. \& J. G. Rodriguez. 1987. Nutritional ecology of dung- and carrion-feeding insects, p. 837-884. In: F. Slansky \& F. G. Rodriguez (ed.) Nutritional ecology of insects, mites, spiders, and related invertebrates. New York, John Wiley \& Sons, 1032 p.

Tachibana, S. I. \& H. Numata. 2001. An artificial diet for blow fly larvae, Lucilia sericata (Meigen)(Diptera: Calliphoridae). Applied Entomology and Zoology 36: 521-523.

Tailor, D. B. \& R. L. Mangan. 1987. Comparison of gelled and meat diets for rearing screwworm, Cochliomyia hominivorax (Diptera: Calliphoridae), larvae. Journal of Economic Entomology 80: 427-432.

Von Zuben, C. J. 1993. Competição larval em Chrysomya megacephala (Diptera: Calliphoridae): Estimativas de perda em biomassa e na fecundidade e cálculo de conversão de alimento em biomassa. Revista Brasileira de Entomologia 37: 793-802.

Von Zuben, C. J. 1998. Comportamento de oviposturas individuais, percentagem de eclosão e peso larval mínimo para pupação em populações de Chrysomya megacephala (F.). Anais da Sociedade Entomológica do Brasil 27: 525-533.

Zumpt, F. 1965. Myiasis in man and animals in the Old World. London, Butterworths, $267 \mathrm{p}$.

Received 28/01/2010; accepted 06/11/2010

Editor: Rodrigo Krüger 